\title{
Elk, sagebrush, and saprotrophs: indirect top-down control on microbial community composition and function
}

\author{
Anna R. Peschel, ${ }^{1}$ Donald R. Zak, ${ }^{1,2,3}$ Lauren C. Cline, ${ }^{1}$ and Zachary Freedman ${ }^{1}$ \\ ${ }^{1}$ School of Natural Resources and Environment, University of Michigan, 440 Church Street, Ann Arbor, Michigan 48109 USA \\ ${ }^{2}$ Department of Ecology and Evolutionary Biology, 830 North University Avenue, University of Michigan, \\ Ann Arbor, Michigan 48109 USA
}

\begin{abstract}
Saprotrophic microbial communities in soil are primarily structured by the availability of growth-limiting resources (i.e., plant detritus), a bottom-up ecological force. However, foraging by native ungulates can alter plant community composition and the nature of detritus entering soil, plausibly exerting an indirect, top-down ecological force that shapes both the composition and function of soil microbial communities. To test this idea, we used physiological assays and molecular approaches to quantify microbial community composition and function inside and outside of replicate, long-term (60-80 yr) winter-foraging exclosures in sagebrush steppe of Wyoming, USA. Winter foraging exclusion substantially increased shrub biomass $\left(2146 \mathrm{~g} / \mathrm{m}^{2}\right.$ vs. $\left.87 \mathrm{~g} / \mathrm{m}^{2}\right)$, which, in turn, increased the abundance of bacterial and fungal genes with lignocellulolytic function; microbial respiration $(+50 \%)$ and net $\mathrm{N}$ mineralization $(+70 \%)$ also were greater in the absence of winter foraging. Our results reveal that winter foraging by native, migratory ungulates in sagebrush steppe exerts an indirect, topdown ecological force that shapes the composition and function of soil microbial communities. Because $\sim 25 \%$ of the Earth's land surface is influenced by grazing animals, this indirect top-down ecological force could function to broadly shape the community membership and physiological capacity of saprotrophic microbial communities in shrub steppe.
\end{abstract}

Key words: bacteria; functional gene; fungi; sagebrush; top-down ecological force; ungulates.

\section{INTRODUCTION}

Soil food webs are thought to be structured by bottom-up ecological forces via the production and biochemistry of plant detritus, the growth-limiting resource for saprotrophic metabolism in soil (Smith and Paul 1990). However, accumulating evidence indicates that soil microbial communities can be influenced by top-down ecological forces, such as the consumption of vegetation by grazing and browsing animals, both large and small (Bardgett and Wardle 2003). For example, ungulate herbivores (e.g., Cervus elaphus, North American elk) could potentially shape microbial communities by altering the biochemical composition of detritus (e.g., dead leaves and roots) entering the soil food web (Hobbs 1996, Ruess et al. 1998, Bardgett and Wardle 2003), as well as through the physiological responses of plants that are induced by plant consumption (e.g., plant production [McNaughton 1985, Holland et al. 1992]). Ungulate herbivory can therefore modify the bottom-up ecological forces that structure soil food webs, thereby potentially linking their consumptive behavior to the composition and function

Manuscript received 26 January 2015; accepted 9 February 2015; final version received 17 March 2015. Corresponding Editor: R. W. Ruess.

${ }^{3}$ Corresponding author. E-mail: drzak@umich.edu of saprotrophic microbial communities in soil. For example, the consumption of plants by ungulate herbivores can influence microbial biomass and rates of soil $\mathrm{N}$ cycling by altering plant community composition and the subsequent production of detritus (Frank and Groffman 1998, Sankaran and Augustine 2004). However, determining the extent to which large herbivores alter community membership and physiological function of soil microbial communities remains a gap in our ecological knowledge (Patra et al. 2005).

Changes in plant composition elicited by herbivory can alter the biochemistry of organic substrates that fuel saprotrophic metabolism (Pastor et al. 1988, Bardgett and Wardle 2003). For example, plants allocate photosynthate to grow or defend against herbivory, wherein fast-growing plants rich in protein (i.e., N) have low levels of metabolically costly plant defenses (e.g., tannins and lignin [Herms and Mattson 1992]). Herbivores also can change plant composition by preferentially consuming the most protein-rich plant material (i.e., $\mathrm{N}$ [McNaughton 1985, Hobbs 1996, Augustine and McNaughton 1998]), which can lead to a dominance of unpalatable plants whose litter slowly decays (Pastor et al. 1988, Augustine and McNaughton 1998). For example, intense moose (Alces alces) browsing on Isle Royale, can over the long term, change forest composition from protein-rich deciduous trees (Populus tremuloides) to spruce (Picea glacua), which has high lignin 
and low protein concentrations (Pastor et al. 1988); this change in forest composition slows soil $\mathrm{N}$ cycling (but also see Kielland et al. 1997, Kielland and Bryant 1998). Conversely, in the Serengeti grasslands of East Africa, intense ungulate grazing shifted photosynthate allocation in graminoids from roots to shoots, causing rapid regrowth of protein-rich leaves after defoliation, as well as more rapid rates of soil $\mathrm{N}$ cycling (Ruess and McNaughton 1987, Seagle et al. 1992, Ruess and Seagle 1994). Presently, we do not understand whether these divergent biogeochemical responses arise from underlying changes in microbial community composition, function, or both.

In contrast to these examples, native migratory ungulates in the Rocky Mountains of North America have a limited forage choice during winter, which has consequences for the subsequent composition of plant communities. To escape deep snow, North American elk (Cervus elaphus) and other migratory ungulates journey from montane forests in autumn to low-elevation valleys to find winter forage (Irwin 2002). In winter, proteinrich forbs and grasses are dormant and hidden by snow; thus, the portion of protein-poor browse (i.e., lignin-rich shrubs) in their diet increases (Irwin 2002). In addition, the energetic cost to search for grasses and forbs beneath deep snow increases, making them less desirable (Parker et al. 1984). Therefore, winter foraging by these animals can decrease woody plant abundance and increase forb and grass abundance in sagebrush steppe (Singer and Renkin 1995, Chong et al. 2011), which has potential consequences for saprotrophic microorganisms in soil.

Plant communities can shape microbial community composition by influencing the organic compounds that enter soil from dead plant leaves and roots (Meier and Bowman 2008, Taylor et al. 2014). Because plant taxa differ in the types of organic compounds contained in leaf and root detritus, substrates for saprotrophic metabolism are provided in different proportions depending on plant community composition. Generally, bacteria enzymatically harvest energy from organic acids and simple sugars. In contrast, some basidiomycete fungi have lignolytic physiologies that enable them to harvest energy by metabolizing polyphenolic compounds, such as lignin, that protect more energetically favorable cellulose and hemicellulose in the plant cell wall (Swift et al. 1979). Taken together, these observations suggest that foraging by native ungulates in sagebrush steppe may alter the composition and function of soil microbial communities by modifying abundance and species composition of woody plants, forbs, and grasses.

Using molecular tools, we quantified microbial community composition and function in the presence and absence of foraging to assess the ecological influence native ungulates may have on saprotrophic microbial communities in sagebrush steppe. If foraging in winter range exerts a direct or indirect, top-down effect on soil microbial community composition and function, exclu- sion of ungulate herbivores should increase shrub abundance, which would favor fungal dominance and a greater abundance of genes with lignocellulolytic function. Because Basidiomycota are the primary agents of lignin metabolism in soil, it follows that their relative abundance should increase with greater shrub dominance in the absence of winter foraging. Alternatively, if ungulate foraging does not structure soil microbial communities, there should be no difference in composition and function of saprotrophic soil microbial communities in the presence or absence of large ungulate herbivores. Here, we provide evidence that soil microbial communities in the sagebrush steppe are structured by the foraging behavior of migratory ungulates, which thereby increases the occurrence of bacteria and fungi with lignocellulolytic physiology.

\section{Methods \\ Site description}

Soil and vegetation were collected in the BridgerTeton National Forest and National Elk Refuge (NER) in Jackson Hole, Wyoming, USA (Table 1). The predominant ecosystem on the valley floor is sagebrush steppe (Knight 1994), and it composes winter range for large ungulate herbivores. Fire is frequent in this drymesic environment, winter precipitation is ample, and the plant community is dominated by bunch grasses and several varieties of Artemisia tridentata (Knight 1994). Mean monthly precipitation is $27.5 \mathrm{~mm}$ (1930-2013), and mean monthly temperature is $2.5^{\circ} \mathrm{C}$ (National Oceanic and Atmospheric Administration 2013). The main native migratory ungulates are North American elk (Cervus elaphus), moose (Alces alces), mule deer (Odocoileus hemionus), American bison (Bison bison), pronghorn (Antilocapra americana), and bighorn sheep (Ovis canadensis). Approximately 60-80 years ago, grazing exclosures were constructed throughout Jackson Hole to understand the influence of ungulate foraging on plant community composition in winter range (Table 1; see Plate 1). Although the exclosures vary in areal extent, they all were constructed using $10 \times 10 \mathrm{~cm}$ steel wire mesh that extends from the soil surface to a height of $3.7 \mathrm{~m}$. Therefore, large ungulate herbivores are excluded from foraging, while small herbivores can move into and out of the exclosures. From 12-19 July 2013, we sampled four exclosures that represent homogenous plant communities in sagebrush steppe. These exclosures are primarily impacted by the winter grazing of North American elk; American bison are absent from three exclosure locations (D. R. Zak, personal observation).

Elk are provided supplemental winter forage on the National Elk Refuge (NER), which lies at the geographic center of our study. This activity, which has taken place since 1912, has maintained a population of $\sim 7500$ individuals wintering on the NER. Although one of our study sites lies within the NER, the others are located at considerable distances in different drainage 
TABLE 1. Physiographic and edaphic characteristics of winter foraging exclosures in northwestern Wyoming.

\begin{tabular}{llcccr}
\hline \hline \multicolumn{1}{c}{ Site } & \multicolumn{1}{c}{ Location } & Elevation $(\mathrm{m})$ & Soil type & Year established & Area $\left(\mathrm{m}^{2}\right)$ \\
\hline Gros Ventre & $43^{\circ} 34^{\prime} 10^{\prime \prime} \mathrm{N}$ & 2263 & fine sandy loam & 1958 & 3721 \\
& $110^{\circ} 18^{\prime} 40^{\prime \prime} \mathrm{W}$ & & & & \\
Lower Hoback & $43^{\circ} 17^{\prime} 45^{\prime \prime} \mathrm{N}$ & 1894 & gravelly loam & 1938 & 961 \\
& $110^{\circ} 39^{\prime} 27^{\prime \prime} \mathrm{W}$ & & & & \\
Miller Butte & $43^{\circ} 30^{\prime} 52^{\prime \prime} \mathrm{N}$ & 1938 & loam/silt loam & 1958 & 10920 \\
& $110^{\circ} 42^{\prime} 42^{\prime \prime} \mathrm{W}$ & & & & \\
Upper Hoback & $43^{\circ} 18^{\prime} 0^{\prime \prime} \mathrm{N}$ & 1951 & gravelly loam & 1938 & 961 \\
& $110^{\circ} 39^{\prime} 38^{\prime \prime} \mathrm{W}$ & & & & \\
\hline
\end{tabular}

systems and represent separate areas of winter range (Table 1). The Gros Ventre site lies in the remote headwaters of the Gros Ventre River drainage, which is $\sim 45 \mathrm{~km}$ northeast of the NER; the Hoback sites lie $\sim 24$ $\mathrm{km}$ directly south of the NER. The Hoback and Gros Ventre sites are areas of winter range that are isolated from the NER by local mountain ranges, whose deep snow restrict the winter movement of elk, thereby containing them on the NER. As such, the Gros Ventre and Hoback sites are not impacted by animals moving into and out of the NER during winter; rather, they are impacted by local populations which winter on range outside the NER.

\section{Plant community composition}

Long-term effects of ungulate foraging on plant community composition were determined by inventorying plant species composition, spatial structure, and aboveground biomass inside and outside of four winterforaging exclosures (Table 1). Inside each exclosure, a 10 $\times 10 \mathrm{~m}$ plot was established at the center. We then established a $10 \times 10 \mathrm{~m}$ plot, $10 \mathrm{~m}$ away from the outside fenced edge of each exclosure; this plot had a matching slope and aspect. Plant cover in this ecosystem is discontinuous, with patches of bare ground and localized accumulations of plant detritus occupying intervening spaces. The patchy nature of plant cover, bare soil, and detritus creates spatial heterogeneity that is an important component of our rationale for how plants affect saprotrophic microbial communities. We made ocular estimates of shrub, forb, and graminoid cover, as well as the cover of the organic horizon and bare soil, within $101-\mathrm{m}^{2}$ sampling frames that were randomly located inside and outside each exclosure. We used these data to simultaneously characterize the composition and spatial structure of the plant community.

Additionally, the aboveground biomass of shrubs, forbs, and graminoids was measured within each $1-\mathrm{m}^{2}$ sampling frame. Forbs and graminoids were clipped, and species-specific allometric equations (Appendix A: Table A1) were used to determine the aboveground biomass of shrubs. Shrubs were clipped if they were $<5 \%$ of total plant cover. Clipped shrubs, forbs, and graminoids were bagged separately, dried at $78^{\circ} \mathrm{C}$, and weighed.

\section{DNA extraction and soil characterization}

To determine the effect of winter foraging on soil microbial community composition and function, one 10 $\mathrm{cm}$ deep mineral soil sample $(2.5 \mathrm{~cm}$ in diameter) was collected from the center of each $1-\mathrm{m}^{2}$ sampling frame after the plant community was inventoried. The 10 soil core samples from each site were composited, homogenized, stored on ice, and shipped to the University of Michigan, where they were kept at $-80^{\circ} \mathrm{C}$ prior to DNA extraction. Homogenized soil samples were passed through a 2-mm sieve, from which genomic DNA was extracted using a MO-BIO PowerLyzer PowerSoil DNA Isolation Kit (MO-BIO laboratories, Carlsbad, California, USA), following manufacturer's instructions. Triplicate extractions were performed on three subsamples of composited soil from each winter-foraged and unforaged plot, providing a total of nine DNA extractions from each site.

Total $\mathrm{N}$, organic $\mathrm{C}$, and soil $\mathrm{pH}$ were measured to characterize soil properties. Soil $\mathrm{pH}$ was measured using a glass electrode, which was inserted into a slurry containing $10 \mathrm{~g}$ of soil and $10 \mathrm{~mL}$ of deionized water. Total soil $\mathrm{N}$ was measured colorimetrically following digestion in concentrated $\mathrm{H}_{2} \mathrm{SO}_{4}$ (Lachat Instruments, Loveland, Colorado, USA). Organic C was determined using a Leco CNS2000 Analyzer (LECO Corporation, St. Joseph, Michigan, USA).

\section{Bacterial and fungal abundance}

Quantitative polymerase chain reaction (qPCR) was performed to gain insight into the effect of large herbivores on the abundance of soil bacteria and fungi. Bacterial abundance was estimated using universal primers Eub338F and Eub518R to amplify 180 bp of the $\mathrm{V} 3$ region of the $16 \mathrm{~S}$ rRNA gene (Fierer et al. 2005). Fungal abundance was estimated using primers ITS1f (Gardes and Bruns 1993) and 5.8S (Vilgalys and Hester 1990) to amplify a $\sim 300$ bp region of the fungal internal transcribed spacer region (ITS). Both fungal and bacterial assays were performed in triplicate on a Stratagene MX3000P real-time PCR (Agilent Technologies, Santa Clara, California, USA) using Brilliant III Ultra Fast SYBR Green qPCR Master Mix (Agilent) following manufacturer's instructions. Further details of our qPCR assay can be found in Freedman and Zak (2014). 


\section{Functional gene analysis}

Following DNA hybridization and data preprocessing (Lu et al. 2011), a subset of GeoChip 5.0 probes $(n=$ 9097) were analyzed to examine the influence of large herbivores on microbial taxonomic composition and functional gene abundance. We included probes encompassing 18 bacterial and 15 fungal functional genes classes that encode enzymes that depolymerize the primary biochemical constituents of plant leaf litter: starch, cutin, cellulose, hemicellulose, and lignin (Eisenlord et al. 2013). The signal intensities of GeoChip hybridization spots were normalized by the Cy5-labeled universal standard DNA across samples and by dividing the signal intensity of each spot by the average intensity of all positive spots within each sample. After normalization, unreliable spots were removed if their original signal intensities were below the noise level $(<2000)$, the signal-to-noise ratio (SNR) was $\leq 2.0$, or the coefficient of variation of the background was $>0.8$. All signal intensities were log-normal transformed. Details of further normalization steps can be found in the supplemental material of $\mathrm{Lu}$ et al. (2011). We analyzed bacterial and fungal genes separately (Appendix B: Table B1); further details of our approach can be found in Eisenlord et al. (2013).

\section{Microbial activity}

Microbial respiration, net $\mathrm{N}$ mineralization, and net nitrification were measured to determine the long-term influence of large herbivores on microbial activity. Three 30 -g soil samples from each foraged and unforaged site were brought to field capacity and incubated at $25^{\circ} \mathrm{C}$ in 1-L Mason jars equipped with septa for headspace gas sampling. Microbial respiration was estimated by measuring $\mathrm{CO}_{2}$ accumulation in the headspace during a 14-d incubation using a Trace 200 Series gas chromatograph (Thermo Electron Corporation, Austin, Texas, USA). To calculate net $\mathrm{N}$ mineralization and net nitrification, the net production of $\mathrm{NH}_{4}^{+}$and $\mathrm{NO}_{3}{ }^{-}$(i.e., final - initial concentrations) in incubated soil samples was measured using an AQ2 discrete analyzer (Seal Analytical, Mequon, Wisconsin, USA).

\section{Statistical analyses}

All statistical analyses were conducted in the software program RStudio (version 0.98.501; R Development Core Team 2014), and significance was accepted at $\alpha=$ 0.05 . To determine the effect of large-herbivore exclusion on plant composition, ordinations were created from principal coordinate analysis ( $\mathrm{PCoA})$ based on the percentage cover of forbs, shrubs, graminoids, organic horizon, and mineral soil, for exclosed and unexclosed plots using the Bray-Curtis dissimilarity metric (Bray and Curtis 1957). Pearson's $r$ correlation coefficients were calculated to explore the relationship of each aforementioned cover variable with PCoA axis 1 or 2 . Permutational multivariate analysis of variance (perMANOVA; Anderson 2001) was used to determine the significance of plant compositional differences between treatments. Plots of $1 \mathrm{~m}^{2}$ were considered nested replicates nested within each treatment plot, with site and treatment as main factors. PerMANOVA allows variation to be partitioned according to the experimental design, and significance is determined by permutations (Anderson 2001). In addition, nested ANOVAs were used to determine differences in shrub, forb, graminoid, organic horizon, and mineral soil percentage cover between treatments.

Nested ANOVAs also were used to determine if ungulate foraging led to differences in microbial respiration, net $\mathrm{N}$ mineralization, and net nitrification over the 14-day incubation, as well as fungal and bacterial abundance. Three replicates for each foraged and unforaged plot were analyzed, with site and treatment as main factors; replicates were nested within treatment. One-way ANOVAs were used to determine whether the exclusion of large herbivores led to differences in shrub, forb, and graminoid biomass, as well as differences in edaphic properties. Biomass and edaphic data were log-transformed prior to analysis.

The GeoChip data matrix from microarray image analysis was normalized to relative abundance by dividing the signal intensity of each individual probe by the total signal intensity of all probes in each sample. The normalized data matrix was analyzed at the gene level (i.e., all genes associated with starch, cutin, cellulose, hemicellulose, and lignin), by summing the normalized signal intensity of all probes attributable to a specific gene and dividing by the number of probes representing a given gene, in order to account for different numbers of probes for any given gene included on GeoChip. Ordinations were created from PCoA based on the normalized signal intensity of each gene of interest. The Bray-Curtis dissimilarity metric was used, and Pearson's $r$ correlation coefficients were calculated to explore the relationship of each functional gene with PCoA axis 1 or 2 .

The effect of large-herbivore foraging on the taxonomic composition of fungal and bacterial functional assemblages was similarly analyzed using multivariate statistics. The GeoChip data matrix, which included probes associated with starch, cutin, cellulose, hemicellulose, and lignin, was converted into a presenceabsence data matrix and reorganized by taxonomic order associated with each probe. This matrix was normalized by summing the presence-absence values of probes associated with each taxonomic order for a given sample, and dividing by the total number of probes associated with a given taxonomic order. Principal coordinate analysis was used to obtain ordinations based on the normalized presence-absence GeoChip data matrix using the Bray-Curtis dissimilarity metric. Pearson's $r$ correlation coefficients were calculated to explore the relationship between bacterial and fungal orders with each PCoA axes. 
PerMANOVA was used to determine if ungulate foraging altered the taxonomic composition, as indicated by GeoChip, and functional composition of fungi and bacteria in the soil. PerMANOVA does not distinguish if dissimilarity between groups is the result of differences in location in multivariate space, differences in each group's relative dispersion, or both (Anderson 2001). Therefore, permutational analysis of multivariate dispersions (PERMDISP; Anderson 2006) was used to determine if significant differences between treatments resulted from differences in assemblage heterogeneity (i.e., the relative dispersion of each treatment from their centroid mean). Similarity Percentage (SIMPER; Clarke and Warwick 2001) was used to ascertain the contribution of each functional gene or microbial order to average dissimilarity between grazing treatments.

\section{Results}

\section{Soil properties and plant biomass}

Soil pH (ANOVA; $F_{1,6}=0.43 ; P=0.56$ ) and soil N (ANOVA; $F_{1,6}=0.36 ; P=0.57$ ) did not differ between foraging treatments. However, soil organic $\mathrm{C}$ increased from $20.3 \mathrm{mg} \mathrm{C} / \mathrm{g}$ in the presence of herbivores to 23.9 $\mathrm{mg} \mathrm{C} / \mathrm{g}$ in the herbivores-excluded treatment (ANOVA; $F_{1,6}=0.16 ; P=0.05$ ), indicating that soil organic matter (Table 1) accumulated in the absence of ungulate herbivores.

Consistent with an increase in soil organic $\mathrm{C}$, the exclusion of ungulate herbivores increased total plant biomass by $\sim 12$-fold, which was $179 \mathrm{~g} / \mathrm{m}^{2}$ in the presence of large herbivores and $2199 \mathrm{~g} / \mathrm{m}^{2}$ in their absence (ANOVA; $F_{1,6}=4.4 ; P=0.08$ ). Additionally, large-herbivore exclusion led to a $\sim 25$-fold increase in shrub biomass ( 87 vs. $2146 \mathrm{~g} / \mathrm{m}^{2}$; foraged vs. unforaged treatment means, respectively; $P=0.07$; Fig. 1 ). The Gros Ventre site had an aberrantly low shrub biomass in the absence of large herbivores; when this site was removed from our analysis, shrub biomass (ANOVA; $F_{1,5}=9.8 ; P=0.026$ ), and total plant biomass (ANOVA; $F_{1,5}=9.3 ; P=0.03$ ) became significantly different between treatments.

Shrub biomass accounted for $\sim 50 \%$ of total plant biomass in the presence of large herbivores and $98 \%$ of total plant biomass in their absence, a response consistent with our hypothesis. Specifically, exclusion of large herbivores increased the biomass of Artemisia tridentata var. vaseyana and Artemisia tridentata var. tridentata. Together, these shrubs accounted for $\sim 40 \%$ of shrub biomass in the absence of large herbivores; the remainder was composed by Persia tridentata and, in some cases, Artemisa arbuscula. Although forb biomass in the presence of ungulate herbivores $\left(65 \mathrm{~g} / \mathrm{m}^{2}\right)$ was two times greater than in their absence $\left(33 \mathrm{~g} / \mathrm{m}^{2}\right)$, this difference was not statistically significant (Fig. 1; ANOVA; $F_{1,6}=3.2 ; P=0.12$ ). In addition, we found no difference in graminoid biomass between treatments (Fig. 1; ANOVA; $F_{1,6}=0.95 ; P=0.51$ ), even though

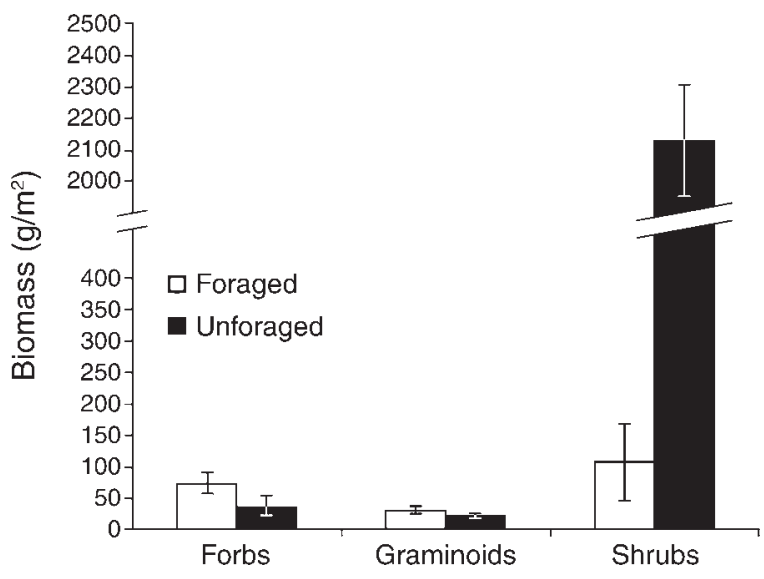

FIG. 1. Forb, graminoid, and shrub biomass in foraged and unforaged treatments. Values are treatment means, and error bars indicate \pm SE. Forb and graminoid biomass were not significantly different between treatments $(P=0.12$ and $P=$ 0.51 , respectively). Shrub biomass was marginally statistically different between treatments $(P=0.07)$ due to unusually low shrub biomass in the unforaged treatment at the Gros Ventre study site $\left(316.7 \mathrm{~g} / \mathrm{m}^{2}\right)$. When this site was removed from our analysis, shrub biomass became statistically significant $(P=$ $0.026)$.

graminoid biomass was $\sim 30 \%$ greater in the presence of large herbivores $\left(26.5 \mathrm{~g} / \mathrm{m}^{2}\right.$ vs. $\left.19.8 \mathrm{~g} / \mathrm{m}^{2}\right)$. The nonsignificant results we report above plausibly arise from the limited degree of replication $(n=4)$ at the treatment level.

\section{Plant community composition}

The exclusion of large herbivores significantly changed plant composition (perMANOVA; pseudo$F_{1,79}=32.4 ; P<0.001$ ). For example, plant communities in the presence of ungulate herbivores were clearly separated along principal coordinate analysis $(\mathrm{PCoA})$ axes 1 and 2, which accounted for $43 \%$ and $14 \%$ of plant community variation, respectively (Fig. 2). Shrub percentage cover was significantly and positively correlated to PCoA axis $1(r=0.97 ; P<0.001)$, whereas mineral soil $(r=-0.80 ; P<0.0001)$, forb $(r=-0.50 ; P<$ $0.001)$, and graminoid $(r=-0.24 ; P<0.05)$ cover were significantly and negatively correlated to PCoA axis 1 . Graminoid $(r=0.70 ; P<0.001)$, organic horizon $(r=$ $0.56 ; P<0.001)$, and forb presence $(r=0.50 ; P<0.001)$ were significantly and positively correlated with PCoA axis 2, but mineral soil $(r=-0.55 ; P<0.001)$ was negatively correlated with PCoA axis 2 .

The exclusion of large herbivores increased shrub cover ( $16 \%$ vs. $48 \%$; ANOVA; $\left.F_{1,73}=94.3 ; P<0.001\right)$. Conversely, foraging exclusion decreased forb cover ( $17 \%$ vs. $11 \%$; ANOVA; $\left.F_{1,73}=44.8 ; P<0.001\right)$, graminoid (19\% vs. $9 \%$; ANOVA; $F_{1,73}=14.2 ; P<$ 0.01 ), and mineral soil cover ( $41 \%$ vs. $20 \%$; ANOVA; $\left.F_{1,73}=40.5 ; P<0.001\right)$. However, herbivore exclusion did not change the percentage cover of the organic horizon ( $8 \%$ vs. $9 \%$; ANOVA; $F_{1,73}=0.29 ; P=0.59$ ). 


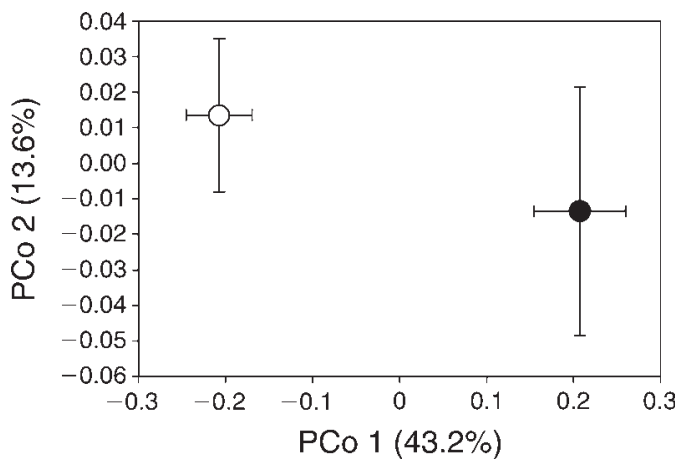

FIG. 2. Principal coordinate analysis (PCoA) visualizing shifts in plant composition and structure due to ungulate foraging. The open symbol is the centroid of the foraged treatment and the solid symbol is the centroid of the unforaged treatment. Error bars indicate \pm SE. The percentage variation accounted for by each axis is shown in parentheses on the axis label. PerMANOVA revealed plant composition between treatments was significantly different $(P<0.001)$. Shrub percentage cover $(r=0.97 ; P=0)$ was positively significantly correlated to PCo axis 1. Mineral soil $(r=-0.80 ; P<0.0001)$, forbs $(r=-0.50 ; P<0.0001)$, and graminoids $(r=-0.24 ; P<$ $0.05)$, were significantly and negatively correlated to PCo axis 1 . Graminoid $(r=0.70 ; P<0.001)$, organic horizon $(r=0.56 ; P<$ $0.001)$, and forbs $(r=0.50 ; P<0.001)$ were significantly and positively correlated with PCo axis 2 . Mineral soil $(r=-0.55 ; P$ $<0.001)$ was negatively correlated with PCo axis 2 .

\section{Microbial activity}

Microbial respiration was $\sim 1.5$ times greater in the absence of large herbivores, relative to rates in their presence (616 vs. $935 \mu \mathrm{g} \mathrm{CO}_{2} / \mathrm{g}$ soil; ANOVA; $F_{1,16}=$ 5.7; $P=0.03)$. Similarly, net $\mathrm{N}$ mineralization was greater when large herbivores were excluded $(7.01 \mu \mathrm{g} \mathrm{N}$ $\mathrm{g}$ soil), compared to rates in their presence $(4.10 \mu \mathrm{g} \mathrm{N} / \mathrm{g}$ soil; ANOVA; $\left.F_{1,16}=23.7 ; P<0.001\right)$. However, net nitrification was similar between treatments (1.66 vs. $1.33 \mu \mathrm{g} \mathrm{N} / \mathrm{g}$ soil; ANOVA; $\left.F_{1,16}=3.1 ; P=0.098\right)$. The significantly greater rates of soil respiration and net $\mathrm{N}$ mineralization in the absence of large herbivores provide evidence that foraging exclusion accelerated soil $\mathrm{C}$ and $\mathrm{N}$ cycling rates, likely due to greater litter production from greater shrub abundance.

\section{Microbial community abundance}

Bacterial 16S rDNA gene copy number was not significantly different in the presence and absence of large herbivores $\left(6.6 \times 10^{5}\right.$ vs. $8.3 \times 10^{5}$ copies $/ g$ soil; ANOVA; $\left.F_{1,11}=1.8 ; P=0.21\right)$, despite the fact that the abundance of this gene was $25 \%$ greater in the absence of large-herbivore foraging. Similarly, there was no effect of foraging exclusion on the relative abundance of the fungal ITS gene copy number $\left(2.3 \times 10^{5}\right.$ vs. $2.7 \times 10^{5}$ copies/g soil; ANOVA; $\left.F_{1,9}=0.78 ; P=0.40\right)$.

\section{Microbial taxonomic and functional composition}

Foraging exclusion changed the taxonomic composition of the soil bacterial community (perMANOVA; pseudo- $F_{1,23}=2.9 ; P=0.041$; Fig. $3 \mathrm{~A}$ ), but did not alter bacterial assemblage heterogeneity (PERMDISP; $F_{1,23}=$ 2.11; $P=0.16$ ), as indicated by GeoChip. Bacterial taxonomic assemblages in the winter-foraged and unforaged treatments were separated by PCoA 1 and 2, which together accounted for $53 \%$ of the variation in taxonomic assemblages (Fig. 3A). Fifty-five out of 73 bacterial orders were significantly and negatively correlated with PCoA axis 1 (Pearson's $r$ correlation coefficients from -0.93 to -0.41 ; Appendix C: Table C1). Actinomycetales correlated most significantly and negatively with PCoA axis 1 (Appendix C: Table C1; $r=$ -0.93 and $P<0.0001)$. Furthermore, SIMPER analysis indicated that bacterial taxonomic composition exhibited a $7 \%$ average dissimilarity between treatments, with the order Synergistales driving the majority of this difference $(3.7 \%)$.

Fungal taxonomic composition (as indicated by GeoChip) was marginally altered by the presence of large-herbivore foraging (perMANOVA; pseudo- $F_{1,23}=$ 2.5; $P=0.08$; Fig. 3B), and were similarly dispersed in ordination space (PERMDISP; $F_{1,22}<0.001 ; P=0.99$ ).
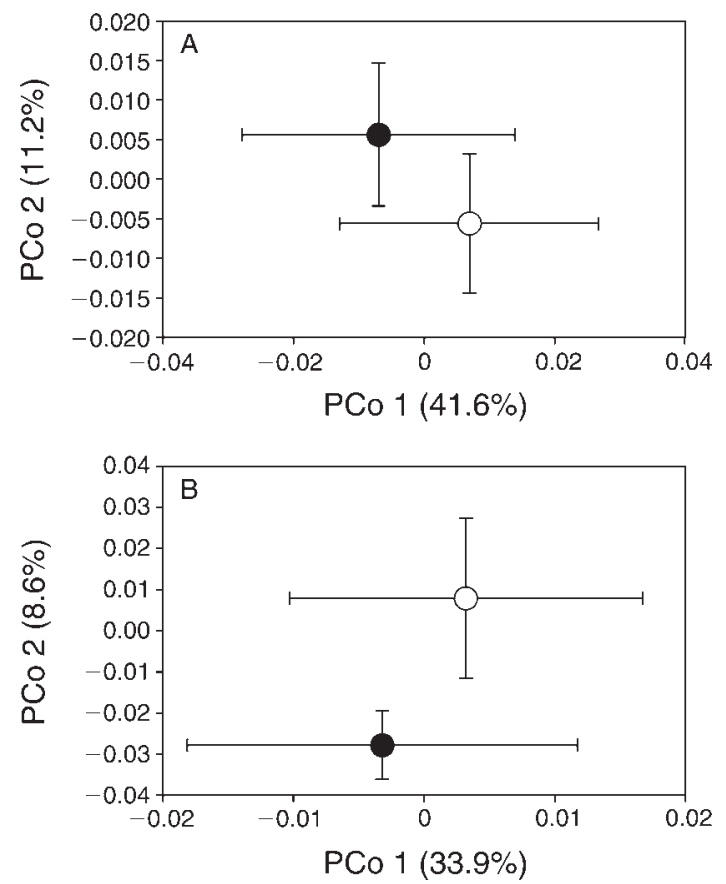

FIG. 3. PCoA visualizing shifts in (A) bacterial and (B) fungal community composition in response to ungulate foraging. The open symbol is the centroid of the foraged treatment and the solid symbol is the centroid of the unforaged treatment. Error bars indicate $\pm \mathrm{SE}$. The percentage variation accounted for by each axis is shown in parentheses on the axis label. Distance matrices were constructed using Bray-Curtis dissimilarity metric based on the presence/absence of all fungal and bacterial orders from functional assemblages. Pairwise comparison with PerMANOVA simulations found significant differences in treatment effects on bacterial community composition $(P=0.042)$, and marginally significant differences in fungal community composition $(P=0.075)$. 
Fungal taxonomic assemblages shifted along PCoA axis 1 and 2, which together accounted for $43 \%$ of the variation (Fig. 3B). Fourteen out of 29 fungal orders were significantly $(P<0.05)$ and negatively correlated to PCoA axis 1 (Appendix C: Table $\mathrm{C} 2$ ). The fungal order Agaricales most strongly and negatively correlated with PCoA axis $1(r=-0.90, P<0.0001)$. SIMPER analysis indicated that fungal richness exhibited $8 \%$ average dissimilarity between treatments; the order Microascales predominately contributed to this difference. We found no difference in the relative abundance of Basidomycotina in the presence and absence of ungulate herbivores.

\section{Microbial community functional composition}

Large-herbivore exclusion significantly altered bacterial functional composition (perMANOVA; pseudo- $F_{1}$, ${ }_{23}=6.1 ; P=0.02$ ), but did not alter assemblage heterogeneity (PERMDISP; $F_{1,22}=0.92 ; P=0.35$ ). Bacterial functional assemblages in the presence and absence of large herbivores separated along PCoA axis 1 and 2, which together accounted for $69 \%$ of the variation (Fig. 4A). Genes encoding enzymes that depolymerize starch, cellulose, and hemicellulose (alpha-amylase, cellobiase, and alpha-L-arabinofuranosidase, respectively) had the strongest negative correlation with PCoA axis 1 (Appendix C: Table C3). In addition, 12 out of 18 lignocellulolytic genes correlated with the exclusion of foraging (Appendix C: Table C3). SIMPER analysis revealed that bacterial functional assemblages exhibited a mean dissimilarity of $\sim 4 \%$, and the gene amy $X$, which encodes starch-hydrolyzing isoamylase, contributed most to dissimilarity between treatments.

Large-herbivore exclusion did not change the composition of fungal functional genes (perMANOVA; pseudo- $\left.F_{1,23}=2.05 ; P=0.15\right)$. However, fungal functional assemblages in the herbivore treatments largely separated along PCoA 2, which, together with PCoA 1 accounted for $64 \%$ of variation (Fig. 4B). Moreover, all fungal lignocellulolytic genes were significantly and negatively correlated to PCoA axis 1 , which marginally separated the herbivore treatments. (Fig. 4B; Appendix C: Table C4). Together, these results suggest that exclusion of large herbivores promoted the presence of bacterial and fungal lignocellulolytic functional genes, which occurred simultaneously with greater shrub abundance and soil organic matter content.

\section{Discussion}

Saprotrophic microbial communities in soil are thought to be structured by bottom-up ecological forces governing resource availability (Smith and Paul 1990); however, our observations provide evidence that this relationship can be modified by the foraging behavior of native ungulates. For example, herbivore consumption of shrubs reduced total plant biomass, which plausibly arose because $A$. tridentata, the most prevalent shrub in our study, is not tolerant to heavy browsing or
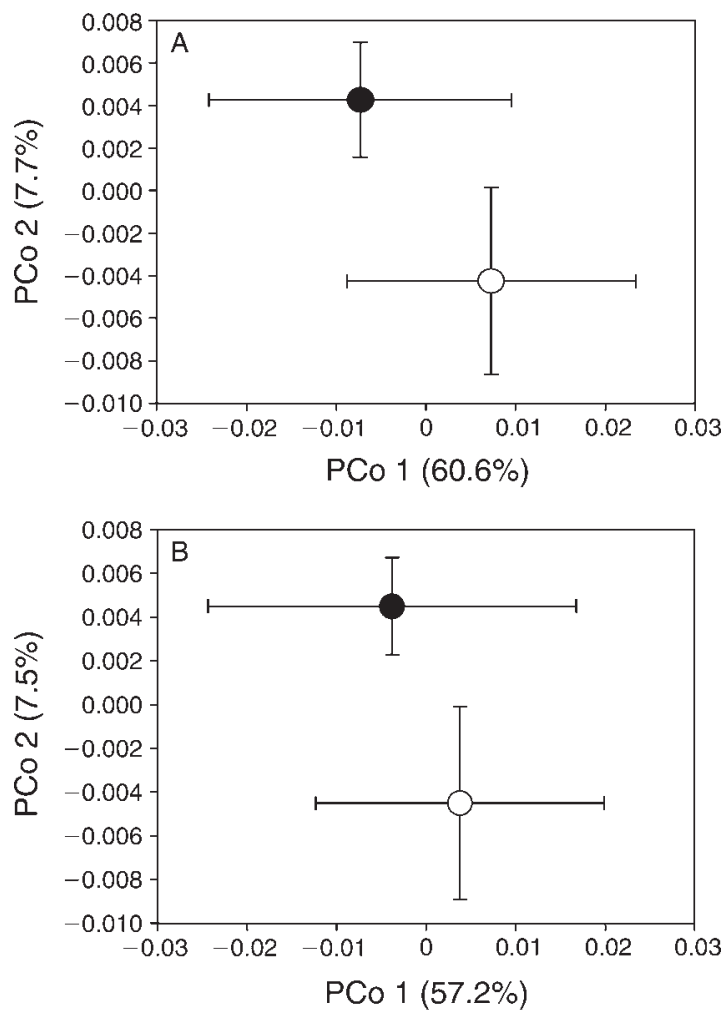

FIG. 4. PCoA visualizing shifts in (A) bacterial and (B) fungal functional assemblages in response to ungulate foraging. The open symbol is the centroid of the foraged treatment and the solid symbol is the centroid of the unforaged treatment. Error bars indicate \pm SE. The percentage variation accounted for by each axis is shown in parentheses on the axis label. Distance matrices were calculated using Bray-Curtis dissimilarity metric based on the normalized signal intensity of all relative gene variants responsible for leaf litter decay. PerMANOVA revealed significant differences in treatment effects for bacterial functional genes $(P=0.015)$ but not for fungal functional genes $(P=0.153)$.

trampling (Bilbrough and Richards 1993). Winter foraging further led to an increase in forb cover, likely because forbs emerge following snowmelt, the time when many ungulates have already migrated to higher elevations, and the forbs thus avoid consumption (Caldwell 1985, Irwin 2002). Taken together, the seasonal migration of native ungulates from high elevations in summer to the valley floor in winter reduced shrub cover and biomass, thereby changing plant composition, which, in turn, modified taxonomic composition, functional potential, and activity (i.e., respiration and net $\mathrm{N}$ mineralization) of soil microbial communities. Our observations are consistent with the idea that winter foraging by migratory ungulates exerts an indirect, top-down ecological force that structures the composition and function of soil microbial communities.

Soil organic $\mathrm{C}$ was greater in the absence of ungulate herbivores, which may be driven by the greater production of slowly decomposing litter from a higher shrub abundance. Shrubs play an important role in 
nutrient regulation in semi-arid ecosystems because their litterfall increases soil organic matter beneath them, relative to adjacent areas outside the shrub canopy (Charley and West 1977). Therefore, the greater shrub biomass and cover may account for $\sim 9 \%$ increase in soil organic $\mathrm{C}$ in the absence of ungulate herbivores compared to their presence. Additionally, A. tridentata presumably contributed to this increase in soil organic $\mathrm{C}$ because its tissues have a high lignin: $\mathrm{N}$ ratio as compared to co-occurring graminoids and forbs in sagebrush steppe (Shaw and Harte 2001, Hooker et al. 2008). The initial lignin content in plant litter is inversely related to the litter decay rate (Prescott 2005), as most saprotrophic microorganisms lack the physiological capacity to oxidize this polyphenolic compound (Paustian et al. 1997). Therefore, lignin from plant detritus enters the resistant pool of soil organic matter, which increases soil organic C (Paustian et al. 1997). Thus, lower amounts of soil organic $\mathrm{C}$ in the presence of ungulate herbivores plausibly arises from the negative effect of these large animals on $A$. tridentata, which, in turn, may have decreased the production of lignified detritus and organic matter accumulation.

Nitrogen mineralization and respiration rates were greater when large herbivores were excluded; these rates also may be driven by increased litter input to soil from a more abundant shrub community. In semi-arid ecosystems, shrubs increase rates of net $\mathrm{N}$ mineralization (Charley and West 1977) and microbial activity (Bolton et al. 1993) due to the localization of litterfall beneath them. Additionally, the accumulation of organic matter can increase soil respiration and regulate net $\mathrm{N}$ mineralization beneath $A$. tridentata (Burke et al. 1989). Therefore, the greater biomass of A. tridentata in the absence of ungulate foraging likely increased the amount of plant material entering the soil food web. This likely increased soil organic C, which, in turn, led to more rapid rates of net $\mathrm{N}$ mineralization and microbial respiration. This response occurred despite the relatively high lignin : N of Artemisia litter.

Our results differ from others who found ungulate grazing increased net $\mathrm{N}$ mineralization (Frank and Groffman 1998, Frank et al. 2000). This contrasting response was driven by ammonium and urea released from ungulate (i.e., elk and bison) urine and fecal pellets (Frank and Groffman 1998, Tracy and Frank 1998, Frank et al. 2000), as well as greater rates of root exudation from grasses that can stimulate soil microbial activity (Hamilton and Frank 2001). Ungulate excreta had not impacted soil $\mathrm{C}$ and $\mathrm{N}$ cycling in our study, because microbial respiration and net $\mathrm{N}$ mineralization were greater in the absence of these animals. In our study area, elk urine and fecal pellets are largely deposited during winter, after which $\mathrm{N}$ could be lost to leaching as the winter snow pack ablates. Further, elk pellets can persist for decades in this relatively arid environment (E. Cole, personal communication), which would slow the release of $\mathrm{N}$ from them. North American elk also primarily occupy our sites during winter, with lower numbers of big horn sheep and mule deer. It is plausible that the greater abundance of bison, which avoid shrubs, may exert an influence on soil $\mathrm{N}$ cycling that differs from elk and other ungulates that occupy winter range in our study area (Frank and Groffman 1998). In our study, greater rates of microbial respiration and net $\mathrm{N}$ mineralization in the absence of winter grazing likely arises from greater detrital production from shrubs.

Winter-foraging exclusion promoted the presence of bacterial functional genes that encode enzymes that metabolize lignified plant litter. Bacterial genes encoding for enzymes that depolymerize starch, cellulose, hemicellulose, and lignin (i.e., compounds found in high abundance in A. tridentata [Kinney and Sugihara 1943]), were highly correlated with winter-foraging exclusion (Appendix C: Table C3). In addition, foraging exclusion altered bacterial and fungal assemblages by favoring taxa with lignocellulolytic physiology. Among bacteria, winter-foraging exclusion promoted the occurrence of organisms in the Actinomycetales order, which have lignolytic physiological capacities (Kluepfel and Ishaque 1982), as well as Synergistales, which can ferment starch (Maune and Tanner 2012). Among fungi, winterforaging exclusion promoted Agaricales and Microascales, orders which encompass a wide range of physiological and ecological attributes. Common Agaricales in soil have the physiological capacity to oxidize lignin and other polyphenols, and Microascales are implicated in the saprotrophic decay of plant detritus (Sakayaroj et al. 2011). However, we are unable to resolve the specific attributes of fungi in our study with the microarray analysis we report; it also likely contributed to our inability to detect differences in Basidiomycotina occurrence between treatments. Nonetheless, the compositional and functional responses that we have documented appear to arise from the increase in A. tridentata biomass in the absence of winter foraging, which likely increased lignin-rich litter detritus production, thereby providing additional substrate for organisms mediating plant litter decay (Raich and Schlesinger 1992, Högberg and Ekblad 1996, Osono 2007).

The greater abundance of $A$. tridentata when winter foraging was excluded likely favored soil bacteria with lignocellulolytic physiologies. Evidence for this assertion comes from the significant differences in bacterial taxonomic and functional assemblages between treatments (perMANOVA; $P=0.042$ and $P=0.015$, respectively), paired with nonsignificant PERMDISP results $(P=0.16$ and $P=0.35$, respectively), together indicating bacterial assemblages were compositionally distinct between large-herbivore treatments. Moreover, bacterial taxa with lignocellulolytic function (e.g., Actinomycetales), as well as genes encoding enzymes that depolymerize starch, cellulose, and hemicellulose ( $\alpha$-amylase, cellobiase, and $\alpha$-L-arabinofuranosidase, respectively) accounted for compositional differences 


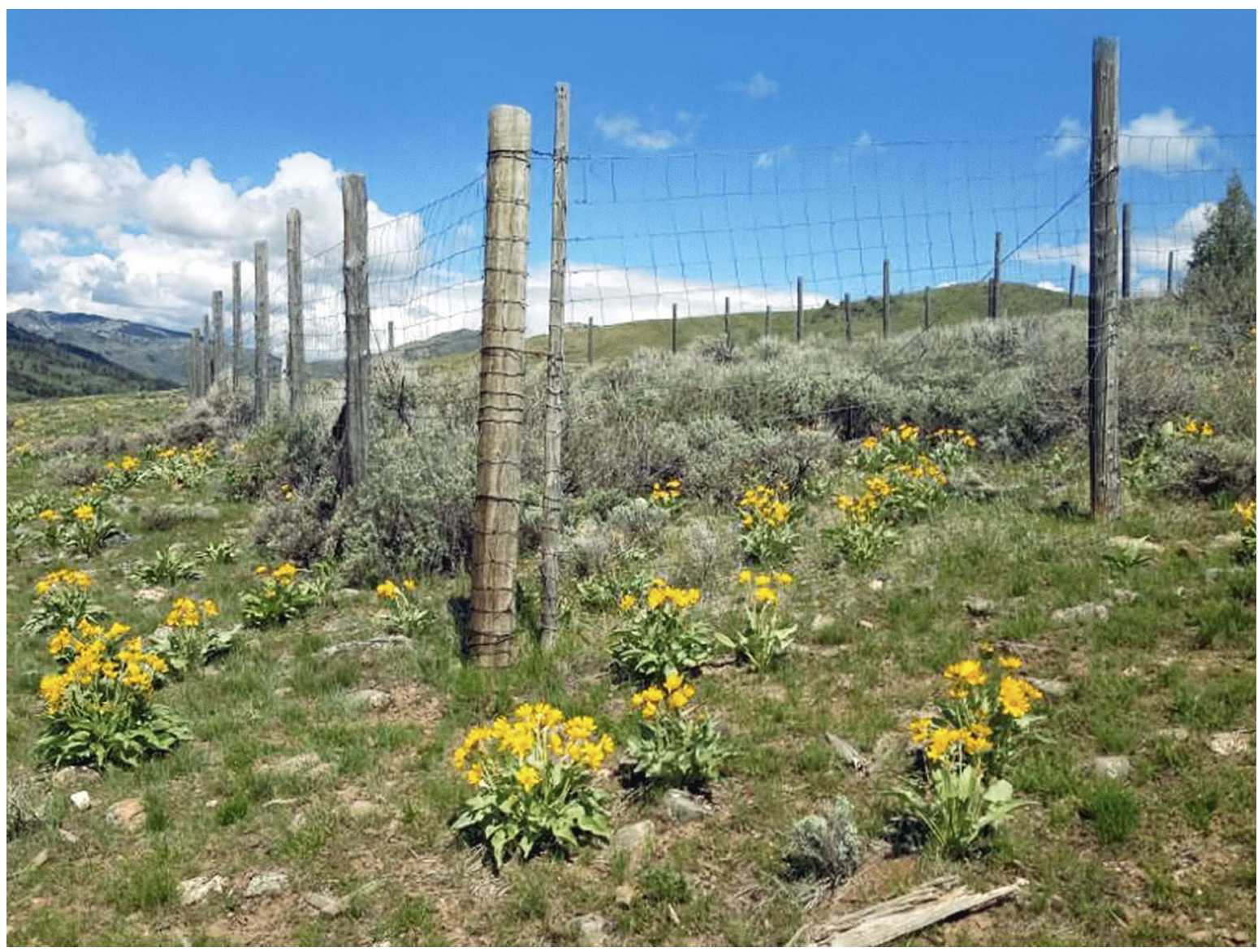

Plate 1. Winter foraging exclosures at one of our study sites. Winter foraging by elk and other large ungulates has decreased shrub abundance, which in turn caused a change in the composition and functions of soil microbial communities. Photo credit: D. R. Zak.

in bacterial assemblages between winter-foraged and unforaged treatments (Appendix C: Tables $\mathrm{C} 1$ and C3). The increase in $A$. tridentata biomass with winterforaging exclusion presumably constrained the soil microbial community by selecting for bacterial taxa better able to enzymatically harvest lignified plant litter.

In contrast, fungal communities in large-herbivore treatments were functionally equivalent, but compositionally distinct. Fungal functional assemblages were similar (perMANOVA; $P=0.15$ ), but taxonomic assemblages were marginally different (perMANOVA, $P=0.076$ ). The significant difference in taxonomic composition suggests competitive displacement within the fungal community in the absence of winter foraging, a response that did not affect the functional potential of this community. Our assessment of functional potential relied on the presence-absence of genes with known lignocellulolytic function, which may not provide a level of resolution that could resolve competitive mechanisms fostering compositional differences between winterforaged and unforaged treatments. Nonetheless, our observations suggest that some level of functional equivalency occurred in the fungal communities of the two herbivore treatments, consistent with the recent observations of Talbot et al. (2014). It is plausible that differences in efficiency of enzymes that mediate the same biochemical process, as well as the differences in substrate-use efficiency among fungal taxa, lie at the heart of these observations. In summary, our results provide evidence that winter foraging by native migratory ungulates in the sagebrush steppe can exert an indirect top-down ecological force that shapes soil microbial communities. Understanding how grazing animals influence the composition and function of soil microorganisms is of broad ecological significance because these organisms mediate the cycling of $\mathrm{C}$ and $\mathrm{N}$ within all terrestrial ecosystems. Therefore, changes to microbial composition and function have the potential to modify the rate at which these elements cycle at local, regional, and global scales (Zak et al. 2011). Furthermore, understanding the ecosystem-level effects of large herbivores is of global importance, because $>25 \%$ of the Earth's land surface is affected by the activity of grazing and browsing animals (Asner et al. 2004). While our study was conducted in the sagebrush steppe of North America, our observations suggest that links may occur 
among foraging animals, plant communities, and the composition and function of saprotrophic microbial communities in other ecosystems where herbivory is an important ecological process.

\section{ACKNOWLEDGMENTS}

We sincerely thank Eric Cole of the National Elk Refuge. He provided us with access to field sites and provided insightful suggestions that improved our field work and data interpretation. Bilal Butt provided insightful comments during the preparation of our manuscript, and Karl J. Romanowiz IV provided assistance with DNA extraction and operating the AQ2 Discrete Analyzer; we sincerely thank them. This research was supported by the School of Natural Resources and Environment, and the Rackham Graduate School at the University of Michigan.

\section{Literature Cited}

Anderson, M. J. 2001. A new method for non-parametric multivariate analysis of variance. Australian Ecology 26:3246.

Anderson, M. J. 2006. Distance-based tests for homogeneity of multivariate dispersions. Biometrics 62:245-253.

Asner, G. P., A. J. Elmore, L. P. Olander, R. E. Martin, and A. T. Harris. 2004. Grazing systems, ecosystems responses, and global change. Annual Review of Environmental Resources 29:261-299.

Augustine, D. J., and S. J. McNaughton. 1998. Ungulate effects on the functional species composition of plant communities: herbivore selectivity and plant tolerance. Journal of Wildlife Management 62:1165-1183.

Bardgett, R. D., and D. A. Wardle. 2003. Herbivore-mediated linkages between aboveground and belowground communities. Ecology 84:2258-2268.

Bilbrough, C. J., and J. H. Richards. 1993. Growth of sagebrush and bitterbrush following simulated winter browsing: mechanisms of tolerance. Ecology 74:481-492.

Bolton, H., J. L. Smith, and S. O. Link. 1993. Soil microbial biomass and activity of a disturbed and undisturbed shrubsteppe ecosystem. Soil Biology and Biochemistry 25:545-552.

Bray, J. R., and J. T. Curtis. 1957. An ordination of the upland forest communities of southern Wisconsin. Ecological Monographs 27:325-349.

Burke, I. C., W. A. Reiners, and D. S. Schimel. 1989. Organic matter turnover in a sagebrush steppe landscape. Biogeochemistry 7:11-31.

Caldwell, M. 1985. Cold desert. Pages 198-211 in B. F. Chabot and H. A. Mooney, editors. Physiological ecology of North American plant communities. Chapman and Hall, New York, New York, USA.

Charley, J. L., and N. E. West. 1977. Micro-patterns of nitrogen mineralization activity in soils of some shrubdominated semi-desert ecosystems of Utah. Soil Biology and Biochemistry 9:357-365.

Chong, G., D. Barnett, B. Chemel, R. Renkin, and P. Sikkink. 2011. Vegetation monitoring to detect and predict vegetation change: connecting historical and future shrub/steppe data in Yellowstone National Park. In Questioning Greater Yellowstone's future: climate, land use, and invasive species. Yellowstone Center for Resources and University of Wyoming William D. Ruckelshaus Institute of Environment and Natural Resources, Laramie, Wyoming, USA.

Clarke, K. R., and R. M. Warwick. 2001. Change in marine communities: an approach to statistical analysis and interpretation. Second edition. PRIMER-E, Plymouth, UK.

Eisenlord, S. D., Z. Freedman, D. R. Zak, K. Xue, Z. He, and J. Zhou. 2013. Microbial mechanisms mediating increased soil $\mathrm{C}$ storage under elevated atmospheric $\mathrm{N}$ deposition. Applied and Environmental Microbiology 79:1191-1199.
Fierer, N., J. A. Jackson, R. Vilgalys, and R. B. Jackson. 2005. Assessment of soil microbial community structure by use of taxon-specific quantitative PCR assays. Applied and Environmental Microbiology 71:4117-4120.

Frank, D. A., and P. M. Groffman. 1998. Ungulate vs. landscape control of soil $\mathrm{C}$ and $\mathrm{N}$ processes in grasslands of Yellowstone National Park. Ecology 79:2229-2241.

Frank, D. A., P. M. Groffman, R. D. Evans, and B. F. Tracy. 2000. Ungulate stimulation of nitrogen cycling and retention in Yellowstone Park grasslands. Oecologia 123:116-121.

Freedman, Z., and D. R. Zak. 2014. Atmospheric N deposition increases bacterial laccase-like multicopper oxidases: implications for organic matter decay. Applied and Environmental Microbiology 80:4460-4468.

Gardes, M., and T. D. Bruns. 1993. ITS primers with enhanced specificity for basidiomycetes-application to the identification of mycorrhizae and rusts. Molecular Ecology 2:113-118.

Hamilton, E. W., and D. A. Frank. 2001. Can plants stimulate soil microbes and their own nutrient supply? Evidence from a grazing tolerant grass. Ecology 82:2397-2402.

Herms, D. A., and W. J. Mattson. 1992. The dilemma of plants: to grow or defend. Quarterly Review of Biology 67:283-335.

Hobbs, N. T. 1996. Modification of ecosystems by ungulates. Journal of Wildlife Management 60:695-713.

Högberg, P., and A. Ekblad. 1996. Substrate-induced respiration measured in situ in a C3-plant ecosystem using additions of C4-sucrose. Soil Biology and Biochemistry 28:1131-1138.

Holland, E. A., W. J. Parton, J. K. Detling, and D. L. Coppock. 1992. Physiological responses of plant populations to herbivory and their consequences for ecosystem nutrient flow. American Naturalist 140:685-706.

Hooker, T. D., J. M. Stark, U. Norton, A. Leffler, M. Peek, and R. Ryel. 2008. Distribution of ecosystem C and N within contrasting vegetation types in a semiarid rangeland in the Great Basin, USA. Biogeochemistry 90:291-308.

Irwin, L. L. 2002. Migration. Pages 493-513 in D. E. Toweill, J. W. Thomas, and D. P. Metz, editors. North American elk ecological management. Smithsonian Institution Press, Washington, D.C., USA.

Kielland, K., and J. Bryant. 1998. Moose herbivory in taiga: effects on biogeochemistry and vegetation dynamics in primary succession. Oikos 82:377-383.

Kielland, K., J. P. Bryant, and R. W. Ruess. 1997. Moose herbivory and carbon turnover in early successional stands in interior Alaska. Oikos 80:25-30.

Kinney, C. R., and J. Sugihara. 1943. Constituents of Artemisia tridentata (American Sage Brush). II. Journal of Organic Chemistry 8:290-294.

Kluepfel, D., and M. Ishaque. 1982. Xylan-induced cellulolytic enzymes in Streptomyces flavogriseus. Developments in Industrial Microbiology 23:389-396.

Knight, D. H. 1994. Mountains and plains: the ecology of Wyoming landscapes. Yale University Press, New Haven, Connecticut, USA.

Lu, M., Y. Yang, Y. Luo, C. Fang, X. Zhou, J. Chen, Xin Yang, and Bo Li. 2011. Responses of ecosystem nitrogen cycle to nitrogen addition: a meta-analysis. New Phytologist 189:1040-1050.

Maune, M. W., and R. S. Tanner. 2012. Description of Anaerobaculum hydrogeniformans sp. nov., an anaerobe that produces hydrogen from glucose, and amended description of the genus Anaerobaculum. International Journal of Systematics and Evolution Microbiology 62:832-838.

McNaughton, S. J. 1985. Ecology of a grazing ecosystem: the Serengeti. Ecological Monographs 55:259-294.

Meier, C. L., and W. D. Bowman. 2008. Links between plant litter chemistry, species diversity, and below-ground ecosystem function. Proceedings of the National Academy of Sciences USA 105:19780-19785.

National Oceanic and Atmospheric Administration. 2013. Annual climatological summary. http://www.noaa.gov 
Osono, T. 2007. Ecology of ligninolytic fungi associated with leaf litter decomposition. Ecological Research 22:955-974.

Parker, K. L., C. T. Robbins, and T. A. Hanley. 1984. Energy expenditures for locomotion by mule deer and elk. Journal of Wildlife Management 48:474-488.

Pastor, J., R. J. Naiman, B. Dewey, and P. McInnes. 1988. Moose, microbes, and the boreal forest. BioScience 38:770 777.

Patra, A. K., et al. 2005. Effects of grazing on microbial functional groups involved in soil $\mathrm{N}$ dynamics. Ecological Monographs 75:65-80.

Paustian, K., G. I. Agren, and E. Bosatta. 1997. Modeling litter quality effects on decomposition and soil organic matter dynamics. Pages 313-335 in G. Cadisch and K. E. Giller, editors. Driven by nature: plant litter quality and decomposition. CAB International, Wallingford, UK.

Prescott, C. E. 2005. Decomposition and mineralization of nutrients from litter and humus. Pages 15-41 in $\mathrm{H}$. BassiriRad, editor. Nutrient acquisition by plants: an ecological perspective. Ecological Studies. Volume 181. Springer, Berlin, Germany.

R Development Core Team. 2014. R: a language and environment for statistical computing (RStudio; version 0.98.501). R Foundation for Statistical Computing, Vienna, Austria.

Raich, J. W., and W. H. Schlesinger. 1992. The global carbon dioxide flux in soil respiration and its relationship to vegetation and climate. Tellus B 44:81-99.

Ruess, R. W., R. L. Hendrick, and J. P. Bryant. 1998. Regulation of fine root dynamics by mammalian browsers in early successional Alaskan taiga forests. [Erratum: April 1999, Volume 80 (3), page 1101.]. Ecology 79:2706-2720.

Ruess, R. W., and S. J. McNaughton. 1987. Grazing and the dynamics of nutrients and energy regulated microbial processes in the Serengeti grasslands. Oikos 49:101-110.

Ruess, R. W., and S. W. Seagle. 1994. Landscape patterns in soil microbial processes in the Serengeti National Park, Tanzania. Ecology 75:892-904.

Sakayaroj, J., K.-L. Pang, and E. B. G. Jones. 2011. Multi-gene phylogeny of the Halosphaeriaceae: its ordinal status, relationships between genera and morphological character evolution. Fungal Diversity 46:87-109.
Sankaran, M., and D. J. Augustine. 2004. Large herbivores suppress decomposer abundance in a semiarid grazing ecosystem. Ecology 85:1052-1061.

Seagle, S. W., S. J. McNaughton, and R. W. Ruess. 1992. Simulated effects of grazing on soil-nitrogen and mineralization in contrasting Serengeti grasslands. Ecology 73:11051123.

Shaw, M. R., and J. Harte. 2001. Control of litter decomposition in a subalpine meadow-sagebrush steppe ecotone under climate change. Ecological Applications 11:1206-1223.

Singer, F. J., and R. A. Renkin. 1995. Effects of browsing by native ungulates on the shrubs in big sagebrush communities in Yellowstone National Park. Great Basin Naturalist 55: 201-212.

Smith, J. L., and E. A. Paul. 1990. The significance of soil microbial biomass estimations. Soil Biology and Biochemistry 6:357-396.

Swift, M. J., O. W. Heal, and J. M. Anderson. 1979. Decomposition in terrestrial ecosystems. Studies in ecology. University of California Press, Berkeley, California, USA.

Talbot, J. M., et al. 2014. Endemism and functional convergence across the North American soil mycobiome. Proceedings of the National Academy of Sciences USA 111:63416346.

Taylor, D. L., T. N. Hollingsworth, J. W. McFarland, N. J. Lennon, C. Nusbaum, and R. W. Ruess. 2014. A first comprehensive census of fungi in soil reveals both hyperdiversity and fine-scale niche partitioning. Ecological Monographs 84:3-20.

Tracy, B. F., and D. A. Frank. 1998. Herbivore influence on soil microbial biomass and nitrogen mineralization in a northern grassland ecosystem: Yellowstone National Park. Oecologia 114:556-562.

Vilgalys, R., and M. Hester. 1990. Rapid genetic identification and mapping of enzymatically amplified ribosomal DNA from several Cryptococcus species. Journal of Bacteriology 172:4238-4246.

Zak, D. R., K. S. Pregitzer, A. J. Burton, I. P. Edwards, and H. Kellner. 2011. Microbial responses to a changing environment: implications for the future functioning of terrestrial ecosystems. Fungal Ecology 4:386-395.

\section{Supplemental Material}

\section{Ecological Archives}

Appendices A-C are available online: http://dx.doi.org/10.1890/15-0164.1.sm 